\title{
Media Literacy: The Albanian perspective
}

\section{Florenc Vavla, PhD Candidate}

\author{
Aleksander Xhuvani University, \\ Faculty of Human Sciences, Department of Journalism \\ Email florivavla@yahoo.com
}

Dr. Laureta Vavla

Aleksander Xhuvani University, Faculty of Human Sciences Department of English and German Languages Email lauretavavla@yahoo.com

Doi:10.5901/jesr.2013.v3n7p737

\section{Abstract}

This paper aims at giving a correct portray of media in Albania with a focus on media literacy and its importance in the Albanian society. In these last decades information has been spread at a higher speed and intensity and as such they are having an enormous impact on humanity. They have become so important that it is rarely that one can live without them. Through using them, people get to know the world around them; they understand the world and try to change it. The whole issue is how to do all this? Sorting out these messages is perhaps one of the most difficult tasks humanity is facing today. Therefore, the necessity for the application and development of media literacy is of ultimate importance and concern. Seen from this point of view, this study constitutes a modest contribution that should serve as an incentive for the youth, parents, educators, teachers and university lecturers to refocus their attention on the role they have to play in media comprehension and understanding.

Keywords: Media literacy, information, education

\section{Introduction}

Throughout all the modern history of the world, information has been considered as a power, and most frequently as the greatest power that controls, steers and plans the development of different situations in the human society. Information became property of a wider public through media which played an increasingly major role on the direction of various developments of humanity, but in the mean time it also became more and more important as well as "attacked" in order to control it, its development, its policy and information development and its people trying therefore to control all of those who follow the media. Obviously this control is absolute in terms of a totalitarian system transforming media into a mere propaganda element of a certain individual or government, while in a functional democracy normally the system should guarantee a completely free and independent media.

Within a democratic system there are rules and laws on which the media operates, but are they able to protect us from the "manipulation" of the media? Are Albanian citizens today threatened by the influx of the extraordinary media control in terms of their opinions on political, social or economic aspects? We now find ourselves facing countless information that come from numerous and various sources. What is more, the rapid development of the internet and the social networks, has also contributed to the immediate spread of this information which in many cases are not popular, irresponsible, non-professional and not infrequently at odds with legal aspects of control by the state.

It seems that in all this "web" of information, the idea as well as the need of raising a generation who "controls the media and who is not controlled by it, is becoming increasingly more and more indispensable. The state alone, cannot fully accomplish the role of the "controller" of this immense influx of information. It is the duty and the demand of the citizens themselves to be able to distinguish the right from the bad, the good from the evil. "Because of the almost exponential explosion of information, we cannot possibly sift through and assimilate all that surrounds us. We are compelled to let others to assess and compress information for us. We are in a sense, victims of our own inability to handle such large quantities of information without confusion." (Lasswell, 1940)

It is the young citizens who need to be equipped with the necessary skills to be "protected" by the media and to 
think independently about the flow of information they receive every day. Therefore, media literacy has become a key skill in the modern times we live in, a skill which in many countries is obtained as part of the school curriculum of the low and middle levels such as primary, elementary and high schools. The same reality should quickly prevail even in those countries that do not yet apply media literacy, including Albania.

Media has become today an important influential element on all human societies throughout the whole world. Naturally, this effect may possess different characteristics where often it appears as a positivist utopia on life by reviving hope and by convincing people that even when the world around them may not be as good and fair as they want it to be, the investment and hard work are worth it because things may improve later on. On the other hand stands the naked or hidden negative aspect of the media, which in the majority of the cases appears in the shape of an "ideology" by "imposing" a definite opinion in favor of the media itself, its owner(s) or those it serves to.

Albania has seen a tremendous development of the media in the recent years and this development has been made in disproportion with the economic and political developments of the country. The idea of private media started after the 90's, thus after the democratic changes in the country, but their greatest actualization happened, at least as far as audiovisual media is concerned, after the year 1996 and it still continues nowadays.

The National Council of Radio and Television, the institution that deals with audiovisual media has a record as of 2012 of three national television stations from which one is a public television, 70 local television channels, 3 digital platforms and 83 cable TVs. Meanwhile there are also 2 national and 56 local radios that operate across the whole country. According to the European Journalism Observatory there are currently 28 national newspapers being published in Albania. These figures show the huge development of the media in the last decades in such a geographically small area.

Furthermore, Albania is the country with the highest growth of Internet users in recent years. Thus, according to statistics gathered from $\mathrm{ClO}$, Communication International Organization, in 2012, Albania has an Internet penetration level of $48.1 \%$ of the population, besides the 2.9 million recorded by the census of that year 1:44 million are active users of the Internet. The average of the EU countries is 61.3 , but it is worth mentioning that Albania is listed before some EU countries like Greece where internet penetration is to the extent of $46.9 \%$.

The internet offers vast possibilities of penetration in any type of information, on various sites and on different type of media including the information coming through social networks. Thus, given the number of people living in Albania and the number of media operating in the area, it can easily be deduced that the media have invaded all our lives, being present at any time and at any place. The flow of information coming from the media can be considered infinite, and if we consider the positive side of this large number of media operating in the area, it can said that we are facing a "media democracy", albeit the problems that each and every medium may represent.

The media deeply influences perceptions, beliefs and attitudes. The importance of visual communication and information is increasing. The effective use of information in society and the need for lifelong learning acquire more and more importance (Jolls and Thoman, 2008). It is consequently not an accident that there is a growing academic interest in questions of literacy, with emphasis on exploring them under the circumstances of the electronic (digital) era, displaying a multidisciplinary mix of specialists in literacy, culture, media education, human-computer interaction, and social studies of technology (Livingstone, 2004).

The media problems with which the Albanian public faces today are probably the same ones that the worldwide audience faces with just small differences.

1. The media programs can often be considered to be far from what might be ideal. In many cases, violence and sex become the greatest influencing factor to the youth.

2. The level of truthfulness and clarity in the information delivered by the media is rather disturbing. This may also be considered as the biggest challenge for the Albanian media. In various media, the same information is represented differently. In the majority of the cases, sensation prevails over the truth.

3. Sometimes the media does not respect the code of ethics. Furthermore, the functioning of journalists' organizations is minimal.

The sketch of the media landscape in the European Commission's Progress Report for Albania in 2012 is far from optimistic: "Editorial independence continues to be hampered by private political and economic interests. There are concerns that public advertising is directed to the television channels that are supportive of the government." The report also mentioned many other issues, such as the pressure of the economic crisis on the media, the lack of employment contracts for journalists as one of the roots of their self-censorship, and government interference in the appointment of public-television managers.

Given these issues this paper is based on the ways that can and should be followed in order to primarily make 
young people less dependent on the media and the negative aspects that it can transmit them. Hence, there exists a very developed situation of the media in all its forms, but on the other hand we have another situation where the entire population is vulnerably located in front of the media, becoming in this way a "loot" of the great interests of the actors and the different stakeholders in the Albanian society.

\section{The importance of media literacy in education.}

Media is a social responsibility (Merrill, 1974) and given this fact, its regulation is concerned with the needs assessment that needs to be made in order to avoid the negative effects it has mainly on the young people. Seen from this viewpoint it is very important for young people to be active and not passive spectators of media, in particular by thinking critically about media. The main purpose is for them to be able to evaluate, access and interpret media messages in order to become so smart as to resist any kind of manipulation and use or misuse by the media. But the questions raised are: what is media literacy? How can one obtain it? Why is it important for our young people? These are difficult questions to be answered. What can be said today is that media literacy is being considered a necessity of life in our societies everywhere in the world. "We live in a world where media are omnipresent. An increasing number of people spend a great deal of time watching television, reading newspapers and magazines, playing records and listening to the radio ... The school and the family share the responsibility of preparing the young person living in a world of powerful images, words and sounds." (UNESCO, 1982)

If media literacy fulfills its function then, there lays a great task in front of each and every one of us. One of the most prominent scholars in this field Hobbs (1998) has come up with a number of questions related to this area. The series of questions, called the 'seven great debates in the media literacy movement', are nonetheless very much worth enumerating as follows:

1. Should media literacy education aim to protect children and young people from negative media influences?

2. Should media production be an essential feature of media literacy education?

3. Should media literacy focus on popular culture texts?

4. Should media literacy have a more explicit political and/or ideological agenda?

5. Should media literacy be focused on school-based K-12 educational environments?

6. Should media literacy be taught as a specialist subject or integrated within the context of existing subjects?

7. Should media literacy initiatives be supported financially by media organizations?

Researching new media literacy at The Massachusetts Institute of Technology (MIT), Jenkins (2008a) addresses the demands of this participatory culture for education. Jenkins claims that the focus of literacy has shifted from individual expression to community involvement. Working together with others has become much more important. Combining this new feature with traditional literacy, research skills, technical skills, and critical analysis skills, Jenkins introduces 12 new core media literacy skills:

- Play - the capacity to experiment with one's surroundings as a form of problem-solving.

- Performance - the ability to adopt alternative identities for the purpose of improvisation and discovery.

- Simulation - the ability to interpret and construct dynamic models of real-world processes.

- Appropriation - the ability to meaningfully sample and remix media content.

- Multitasking - the ability to scan one's environment and shift focus as needed to salient details.

- Distributed cognition - the ability to interact meaningfully with tools that expand mental capacities.

- Collective intelligence - the ability to pool knowledge and compare notes with others toward a common goal.

- Judgment - the ability to evaluate the reliability and credibility of different information sources.

- Transmedia navigation - the ability to follow the flow of stories and information across multiple modalities.

- Networking - the ability to search for, synthesize, and disseminate information.

- Negotiation - the ability to travel across diverse communities, discerning and respecting multiple perspectives, and grasping and following alternative norms.

- Visualization - the ability to interpret and create data representations for the purposes of expressing ideas, finding patterns, and identifying trends (Jenkins et al., 2008b).

It suffices to mention the fact that today media literacy itself is divided into several literacy skills that researchers are studying more and more. So for instance, visual literacy is one of the most recent terms that is defined as follows:

Visual Literacy refers to a group of vision-competencies a human being can develop by seeing and at the same time having and integrating other sensory experiences. The development of these competencies is fundamental to normal human learning. When developed, they enable a visually literate person to discriminate and interpret the visible 
actions, objects, symbols, natural or man-made, that he encounters in his environment. Through the creative use of these competencies, he is able to communicate with others. Through the appreciative use of these competencies, he is able to comprehend and enjoy the masterworks of visual communication. (IVLA, 2009)

So as to be fully engaged in the study of this area it is necessary to have the adequate knowledge in critical thinking combined with pedagogical criticism, which are basic elements of media literacy. The combination of these elements will be extremely important as it leads to data collection, different materials, teaching methods, monitoring and evaluation methods.

The study of media literacy can not only focus on critical thinking but also in the context of the critical methodology meaning that it does not aim simply the knowledge acquisition but also in the knowledge usage.

Pedagogical media literacy, aims to answer some questions that everyone should make on the authorship information, (who sends this information and why?), its purpose (as another might interpret this information in a different way), views (what lifestyle and values are reflected), methods used (what techniques are used to attract attention to this information?) and outputs (such as how are media messages created?). (Hoobs 2005; 60)

It is worth inspecting a Canadian approach, as well. The definition by the Ontario Association for Media Literacy (AML), cited by Duncan (2006), puts emphasis on the educational aspect: Media literacy is concerned with developing an informed and critical understanding of the nature of the mass media, the techniques used by them, and the impact of these techniques. It is education that aims to increase students' understanding and enjoyment of how the media work, how they produce meaning, how they are organized, and how they construct reality. Media literacy also aims to provide students with the ability to create media products. (Duncan, 2006). Gutiérrez Martín and Hottmann (2006) also add that on a more specific level - media literacy has to do with education, the primary objective of which is the following: To increase students' understanding and enjoyment of media, facilitate understanding of how the media produce meaning, how they are organized, and how they construct their own reality - all this while keeping in mind the skills and knowledge necessary to create media products. (Gutiérrez Martín and Hottmann, 2006).

The demand to answer all the above questions regarding media literacy is closely related to the fact that society should not be allowed to be used and misused by the media. Naturally, such an objective is going to be achieved through continuous education as well as through giving practical answers to questions such as : why should we learn, what should we learn and how should we learn?

James Potter (2004:66) states that 'any theory of media should be at its core a theory about how people are affected by the media. "During the 1990s, British, Canadians, Australians, Americans outlined the idea that media literacy would be the appropriate solution to the problem of negative influences of the media in society." (Hobbs, 2005). The solution to this problem in the modern society is based not only on awareness of media researchers, but also based on the collaboration of educators through media literacy, to raise awareness on the impact of media in everyday life. Other authors such as Buckingham stated that media education is the solution to this problem. "(Buckingham, 2003:6).

Studies and articles about media literacy in recent years have attracted more and more attention and research on Google about this term in 2008 were 3.14 million. This shows that media literacy is attracting more and more attention of researchers as an essential civic skill in the chaotic and versatile Information Age of the modern societies.

\section{Conclusion}

Media play an important role in the way people think about their country. A new culture of information is evolving especially in the Albanian society. There is a civic illiteracy about Media in general. People want to know what is happening to them and they want to know what they can do about it. But the problem is how to deal with all this. Hence, Media literacy becomes of great importance. It has to do with film and television, press and radio and their impact on the society. Its aim is to enable the youth to develop critical thinking skills, to analyze and positively reflect on their life experiences while using various media.

It has been speculated that the media are often telling us what should and should not be important to us socially, culturally, educationally, politically and economically. Disputes are being held about the abuses of the press, about invasion of privacy, about the right of the media to inquire into the life of many people, etc. Despite this criticism of the mass media, most thoughtful people agree that these same media are doing a great job in reporting news all over the world and into informing the public. It is our task than to help people and especially the youth through Media Literacy to correctly receive and understand this information, transmit it to the coming generations and try to use this knowledge to the benefit of the society. 


\section{References}

Masterman, L. \& Mariet, F. (1994). Media Education in 1990s Europe. A Teacher's Guide. Council of Europe Press.

Masterman, L. (1997).A Rationale for Media Education. In Kubey, R. (Ed.).Media Literacy in the Information Age. New Brunswick,.

Lull, J. (2000). Media, Communication, Culture: A Global Approach. Polity Press.

Livingstone, S. (2002). Young People and New Media. London: SAGE

Hobbs, R. (1996). Expanding the Concept of Literacy. In R. Kubey (Ed.), Media Literacy in the Information Age.

Hobbs, R. (1997b). Literacy for the Information Age. In J. Flood, S. B. Heath, \&Lapp,

D. (Eds.), Hand book of Research on Teaching Literacy through the Communicative and Visual Arts

Hobbs, R. (2005). The State of Media literacy Education, Joumal of communication, vol. 55. International Communication Association.

Jenkins, H. (2008a), "Confronting the challenges of participatory culture - media education for the21st century", occasional paper on digital media and learning, The MacArthurFoundation, Chicago, IL

Hall, S. (1980). Encoding/Decoding, InS. Hall et al. (Eds.) Culture, Media, Language London: Hutchinson.

IVLA (International Visual Literacy Association) (2009) What is 'Visual Literacy?' Available (consulted July 2009) at: http://www.ivla.org/org_what_vis_lit.htm

Gutiérrez Martín AG and Hottmann A (2006) Media Education across the Curriculum. Kulturring in Berlin e.V. Available (consulted July 2009) at: http://www.mediaeducation.net/resource/pdf/downloadMEACbooklet.pdf

Frechette, J. D. (2002). Developing Media Literacy in Cyberspace: Pedagogy and Critical Learning for the Twenty-first- Century Classroom. westport, Conn. Greenwood Publishing Group.

Ennis, R. (1989). 'Critical thinking and subject-specificity: clarification and needed research', Educational Researcher. 18, pp.4-1 0.

Ennis, R. H. (1996). Critical Thinking. Upper Saddle River. N.J.: Prentice Hall 236

Duncan, B. (Ed.). (1989). Media Literacy Resource Guide. Toronto: Ministry of Education of Ontario, Publications Branch, the Queen's Printer, $232 \mathrm{p}$.

Dines, G., \& Humez, J. (1995), (Eds). Gender, Race, and Class in Media. Thousand Oaks, Ca. and London: Sage

Considine, D. M. (2003). Weapons of Mass Destruction? Media Literacy, Social Studies \& Citizenship. In B. Duncan \& K. Tyner (Eds.), Visions/Revisions: Moving Forward with Media Education (pp. 1-16). Madison, Wl: National Telemedia Council.

Considine, D. M., \& Haley, G.E. (1999). Visual Messages: Integrating Imagery into Instruction. Englewood, CO: Teacher Ideas Press.

Cantor, J. (2002). Fright Reactions to Mass Media. In J. Bryant and D. Zillmann (Eds). Media Effects: Advances in Theory and Research, (2nd Ed). pp.287-306. Mahwah, NJ: Lawrence Erlbaum Associates.

Buckingham, D. (2003). Media Education-Literacy, Leaming and Contemporary Culture. Polity Press in Association with Blackwell Publishing Ltd.

Buckingham, D. (1998a). Media Education in the UK: Moving Beyond Protectionism. Joumal of Communication, 48(1), pp.33-43.

Buckingham, D. (Ed.). (1998b). Teaching Popular Culture: Beyond Radical Pedagogy. London: University College London Press.

Buckingham, D. \& Sefton-Green, J. (1997). Multimedia Education: Media Literacy in the Age of Digital Culture. Julkaisussa Kubey, R. (Ed.) Media Literacy in the Infonnation Age. Current Perspectives. Information and Behaviour. vol. VI. pp.285- 305. New Brunswick, NJ: Transaction Publishers.

Buckingham, D. (1990). watching Media Learning: Making Sense of Media Education. London: The Flamer Press.

Buckingham, D. (1993b). Children Talking Television: The Making of Television Literacy. Washington, DC: Falmer Press.

Buckingham, D. (1996). Critical Pedagogy and Media Education: A Theory in Search of a Practice. Journal of Curriculum Studies,

Brown, J. A. (1991). Television "Critical Viewing Skills" Education: Major Media Literacy Projects in the United States and Selected Countries. Hillsdale, NJ: Lawrence Erlbaum.

Brown, J. A. (1998). Media Literacy Perspectives. Joumal of Communication,

Bower, C. A. (1987). Elements of Post-liberal Theory of Education. New York: Teachers College Press.

Brereton, P. (2001). Media Education. TJ International Ltd, Padstow. Cornwall.

Adams, D. M., \& Hamm, M. E. (1989). Media and Literacy: Learning in an Electronic Age: Issues, Ideas, and Teaching Strategies. Springfield IL: Thomas.

Adams, D. M., \& Hamm, M. E. (2001). Literacy in a Multimedia Age. 